\title{
Effect of termite activity on soil under different land management strategies
}

\section{Efeito da atividade de térmitas no solo sob diferentes manejos}

\author{
Liane Barreto Alves Pinheiro ${ }^{1}$; Rodrigo Camara ${ }^{2}$; Marcos Gervasio Pereira ${ }^{3 *}$; \\ Eduardo Lima ${ }^{4}$; Maria Elizabeth Fernandes Correia ${ }^{5}$; Cristiane Miranda Martins ${ }^{6}$; \\ Everaldo Zonta ${ }^{7}$; Carlos Eduardo Gabriel Menezes ${ }^{8}$
}

\begin{abstract}
Mound-building termites are important agents of soil bioperturbation, but these species have not been extensively studied thus far. The present study aimed to evaluate the soil particle-size and the chemical attributes of termite mounds and the surrounding soil under different land use strategies. A one-hectare plot was defined for an unmanaged degraded pasture, planted pasture, and for a eucalyptus Corymbia citriodora plantation. In each plot, the top, center, and base sections of five Cornitermes cumulans mounds, and the surrounding soil at the depths of $0-5 ; 5-10 ; 10-20 \mathrm{~cm}$, were sampled in the Pinheiral, Rio de Janeiro state. In the three areas, the center of the mounds contained higher clay content, organic carbon, phosphorous, calcium and magnesium, total bases, and cation exchangeable capacity, when compared to the top, base, and the surrounding soils. However, the center had lower values of exchangeable acidity and potassium, of the three areas. In the eucalyptus plantation, the values of $\mathrm{pH}$, total bases, calcium, and magnesium were lower, whereas aluminum, exchangeable acidity, sodium, and cation exchange capacity were higher both in the mounds and in the surrounding soil, in relation to the pastures. There were no differences among the three areas in terms of organic carbon, potassium, phosphorous, and total bases, in the mounds and adjacent soil. Thus, the termite activity altered the clay content and most of the soil chemical properties in all of the studied areas, but only for the center of the mounds. However, the effect of these organisms was different in the eucalyptus plantation in relation to the pasture areas.
\end{abstract}

Key words: Cornitermes cumulans. Edaphic properties. Eucalyptus plantations. Mound-building termites. Pasture.

\footnotetext{
${ }^{1}$ Eng $^{\mathrm{a}}$ Florestal, Dra ${ }^{\mathrm{a}}$, Tecnologista de Informações Geográficas e Estatísticas, Departamento de Recursos Naturais, Diretoria de Geociências, DGC, Fundação Instituto Brasileiro de Geografia e Estatística, IBGE, Rio de Janeiro, RJ, Brasil. E-mail: liane. pinheiro@ibge.gov.br

${ }^{2}$ Eng $^{\circ}$ Agr $^{\circ}$, Prof. Dr. Colaborador, Instituto de Florestas, Universidade Federal Rural do Rio de Janeiro, UFRRJ, Bolsista do Programa Nacional de Pós-Doutorado, PNPD, Coordenação de Aperfeiçoamento de Pessoal de Nível Superior, CAPES, Seropédica, RJ, Brasil. E-mail: rcamara73@gmail.com

${ }^{3} \mathrm{Eng}^{\mathrm{o}} \mathrm{Agr}^{\mathrm{o}}$, Prof. Dr. Titular, Departamento de Solos, UFRRJ, Seropédica, RJ, Brasil. E-mail: gervasio@ufrrj.br

${ }^{4} \mathrm{Eng}^{\mathrm{o}} \mathrm{Agr}^{\mathrm{O}}$, Prof. Dr. Adjunto III, Departamento de Solos, Seropédica, RJ, Brasil. E-mail: edulima@ufrrj.br

${ }^{5}$ Bióloga, Dra, Pesquisadora, Empresa Brasileira de Pesquisa Agropecuária, EMBRAPA Agrobiologia, Seropédica, RJ, Brasil. E-mail: elizabeth.correia@embrapa.br

${ }^{6}$ Eng $^{\mathrm{a}}$ Agr ${ }^{\mathrm{a}}$, Dr ${ }^{\mathrm{a}}$, Instituto Federal de Educação, Ciência e Tecnologia do Tocantins, IFTO, Paraíso do Tocantins, TO, Brasil. E-mail: cristiane@ifto.edu.br

${ }^{7}$ Eng $^{\mathrm{o}}$ Agr $^{\circ}$, Prof. Dr. Associado II, Departamento de Solos, UFRRJ, Bolsista do CNPq. E-mail: ezonta@ufrrj.br

${ }^{8}$ Licenciado em Ciências Agrícolas, Prof. Dr., Instituto Federal de Educação, Ciência e Tecnologia do Rio de Janeiro, IFF, Campus Nilo Peçanha, Pinheiral, RJ, Brasil. E-mail: carlos.menezes@ifrj.edu.br

* Author for correpondence
} 


\section{Resumo}

Térmitas construtores de montículos são importantes agentes modificadores do solo, mas estudos são necessários para a melhor compreensão deste processo. O presente estudo objetivou avaliar a granulometria e os atributos químicos do material formador de montículos de térmitas e compará-los com o solo adjacente não trabalhado pelos organismos, em diferentes tipos de manejo do solo. Coletouse o material individualizado em topo, base e centro de cinco montículos de Cornitermes cumulans, bem como do solo adjacente não trabalhado (camadas de 0-5, 5-10 e 10-20 cm), em 1 ha demarcado em áreas de pastagem não manejada degradada, pastagem formada e plantio do eucalipto Corymbia citriodora, em Pinheiral, RJ. Nestas três áreas, a seção central dos montículos apresentou maiores valores de conteúdo de argila, carbono orgânico, fósforo, cálcio e magnésio, soma de bases e capacidade de troca catiônica, em comparação com o topo, base e o solo adjacente. Contudo, no centro dos montículos observou-se menores valores de acidez extraível e potássio, em relação ao topo, base e o solo adjacente nas áreas estudadas. No plantio de eucalipto, os valores de $\mathrm{pH}$, soma de bases, cálcio e magnésio foram menores, enquanto que os valores de alumínio, acidez extraível, sódio e capacidade de troca catiônica foram maiores, nos termiteiros e no solo adjacente, quando comparado com as pastagens. Não houve diferença entre as áreas estudadas quanto aos valores de carbono orgânico, potássio, fósforo e soma de bases, nos montículos e no solo adjacente. Assim, a atividade dos térmitas alterou o conteúdo de argila e a maioria dos atributos químicos do solo em todas as áreas estudadas, mas apenas no centro dos termiteiros. Contudo, o efeito destes organismos foi diferente no plantio de eucalipto, em relação às pastagens.

Palavras-chave: Cornitermes cumulans. Cupins-de-montículos. Pastagem. Plantio de eucalipto. Propriedades do solo.

\section{Introduction}

The order Isoptera is represented by 3,000 species of termites (cupim), of which approximately $75 \%$ build nests on the ground called mounds (SARCINELLI et al., 2009). The species belonging to the genus Cornitermes are responsible for the construction of the vast majority of these structures, most of which are found on the surface of the soil (FERREIRA et al., 2011). In Brazil, the term "mound-building cupim" has been associated almost exclusively with the species Cornitermes cumulans (Kollar, 1832), due to the high frequency with which their nests can be found; these are mainly in pastures in the Southeast, as well as in parts of the Central-West, South, and Northeast regions of Brazil (VALÉRIO, 2006). This species builds mounds in a conical shape, which can reach average and maximum heights of $77.7 \mathrm{~cm}$ and $200 \mathrm{~cm}$, respectively (REDFORD, 1984), a basal diameter of $110 \mathrm{~cm}$, and an outer wall thickness between 3-5 cm (COSARINSKY, 2011).

Termite mounds are found more frequently, and with greater density and affluence in ecosystems that have been most impacted by human activities, compared to areas that were less impacted, or areas with native vegetation. This was verified in an old pasture (9 years), compared to regenerated pastures and native "cerrado" vegetation in Planaltina, Goiás (BENITO et al., 2004); an integrated crop/ livestock system and continuous pasture area, compared to an area of native "cerrado" vegetation in Dourados, Mato Grosso do Sul (SILVA et al., 2006); and a degraded pasture still occupied by cattle and two areas of abandoned pasture that had remained undisturbed for 5 and 30 years, with scrub regeneration, in Poço Redondo and Porto da Folha, Sergipe (VIANA JÚNIOR et al., 2014). The proliferation of these social insects in these landscapes, where organic matter with a high $\mathrm{C} / \mathrm{N}$ ratio predominates in the soil, is probably related to their capacity to co-exist with microorganisms that help with the decomposition of such material (BENITO et al., 2004; AQUINO et al., 2008).

Therefore, termites are considered aesthetic pests (FERNANDES et al., 1998), and an indicator of pasture degradation (AQUINO et al., 2008). 
However, changes in the physical and chemical properties of the soil caused by the activity of termites, which for this reason are considered ecosystem engineers (DANGERFIELD et al., 1998), are positive. This is due to the increase in $\mathrm{pH}$, porosity, clay content, organic matter, and nutrients in termite nests, as compared with the surrounding soil that has not been affected by these organisms (ACKERMAN et al., 2007; SARCINELLI et al., 2009; COSARINSKY, 2011; ECHEZONA et al., 2012; SARCINELLI et al., 2013). It is known that the resistant outer layer of the mounds built by Cornitermes cumulans is mainly made of soil, while the central chamber where the colony lives is rich in organic matter (REDFORD, 1984; FERREIRA et al., 2011).

However, these results considered all mounds constructed by different species of cupim, or by species that do not belong to the genus Cornitermes, and they were based on the comparison of surrounding soil with material present within $10 \mathrm{~cm}$ of the termite nests (the top) (ACKERMAN et al., 2007; ECHEZONA et al., 2012; SARCINELLI et al., 2013), with the external wall and the inner part of the termite nests (SARCINELLI et al., 2009) or with only the outer wall (COSARINSKY, 2011). Nevertheless, these studies were conducted in pasture areas and/or areas of natural regeneration of native vegetation, and there is no data of this kind referring to eucalyptus plantations, which is a type of soil management widely used in many different soil and climatic conditions.

In addition, information about the effect of termite activity on soil, by comparing different sections within termite nests in a vertical gradient (top, center, and base), and comparing these sections to the surrounding soil, were reported by Kaschuk et al. (2006). This type of approach is based on the hypothesis that the different sections have different chemical compositions. This fact is consistent with field observations in pasture areas and eucalyptus plantations in Pinheiral, a municipality in the state of Rio de Janeiro, where the outer wall of the mounds was found to be quite tough and reddish. However, the internal walls in the central section are fragile and very dark, with various galleries constructed mostly from excrement. Thus, the influence of termites and their mounds on soil formation, landscape transformation, nutrient cycling, and as bioindicators of disturbance of tropical ecosystems have not been investigated adequately (JOUQUET et al., 2014). Further studies should be carried out to examine the important ecological role of these organisms in different ecosystems (FERREIRA et al., 2011). The present study aimed to identify possible relational patterns between the surrounding soil under different types of land management, and different sections of the termite nests created by Cornitermes cumulans, considering the texture and chemical attributes of the material used to form the mounds in Pinheiral, Rio de Janeiro.

\section{Material and Methods}

The study area was located in the municipality of Pinheiral, which belongs to the Middle Valley of the Paraíba do Sul region, in the state of Rio de Janeiro, between latitudes $22^{\circ} 30^{\prime} \mathrm{S}$ and $22^{\circ}$ $38^{\prime} \mathrm{S}$ and longitude $43^{\circ} 57^{\prime} \mathrm{W}$ and $44^{\circ} 05^{\prime} \mathrm{W}$. The topography is similar to the "Mar de Morros" type (AB'SABER, 1996), with small areas of wetlands associated with high slope areas, whose altitude varies between $360 \mathrm{~m}$ and $720 \mathrm{~m}$. The climate of the region is classified as Cwa, with a temperate dry winter and rainy summer, and as Am, with tropical humid characteristics and a dry winter (KÖPPEN, 1948). The total annual rainfall varies between 1300 $\mathrm{mm}$ and $1500 \mathrm{~mm}$, which is concentrated between December and March, while the dry season occurs during the months of July to September (PINHEIRO et al., 2013). The monthly average temperature ranges between $12^{\circ} \mathrm{C}$ and $33^{\circ} \mathrm{C}$, with an annual average of $20.9^{\circ} \mathrm{C}$. The native vegetation in the area is called Low Mountainous Rainforest and belongs to the wider region of the Atlantic Forest (VELOSO et al., 1991). 
This study was conducted in areas with three different types of soil management, which are prevalent in the region and have a high frequency of termite mounds: (1) unmanaged degraded pasture (UP) dominated by the Paspalum notatum grass (Fluegge) with invasive plant species such as Vernonia polyanthes (L.), Solanum aculeatissimum (Jacq.), and Baccharis dracunculifolia (D. C.); (2) managed pasture (MP) with Brachiaria decumbens (Stapf) planted through conventional tillage practices (liming and mineral fertilization); and (3) Corymbia citriodora eucalyptus plantations (Hill and Johnson) (EU). The MP area is subjected to increased grazing pressure, due to the higher quality of the pasture, in comparison with the UP area. In this area, there is alternating use of initial secondary vegetation ("capoeira") and unmanaged pasture, as well as the widespread practice of burning. Both UP and MP areas are occasionally mowed. The EU was planted in 1982 through the establishment of contoured ridges, with lime and mineral soil fertilization for the unmanaged pasture, and the first cut was made in 1996. In all three areas studied, the soil is classified as Red-Yellow Acrisol (SANTOS et al., 2013).

In each area (UP, MP, and EU) a plot of about one hectare was randomly outlined, from which samples of the formation material of five termite mounds inhabited by Cornitermes cumulans were collected; these were considered the sample units. This procedure was intended to meet the minimum principles for collecting soil samples for fertility purposes, where the recommendation is to obtain 10-20 single samples to constitute a standard-area sample, which is equal to 1 ha. In the dry season (late winter) and rainy season (late summer), approximately $500 \mathrm{~g}$ of soil samples were collected from the upper sections (top), middle sections (center), and bottom sections (base) of the mounds. During winter, the average temperature is $19^{\circ} \mathrm{C}$ and the average monthly precipitation is $47.5 \mathrm{~mm}$, while in summer, the average temperature is $24^{\circ} \mathrm{C}$ and the average monthly precipitation is $192 \mathrm{~mm}$, according to data from the Pinheiral Weather Station. The vertical distance between the collection points in sections of termite nests has not been fixed, since this varied depending on the size of the termite nests.

As a comparative control, approximately $550 \mathrm{~g}$ of soil samples were also collected in a surrounding area adjacent soil at depth levels of 0-5 cm, 5-10 $\mathrm{cm}$, and 10-20 $\mathrm{cm}$ below the surface and at a distance of approximately $2 \mathrm{~m}$ from each mounds, to avoid the influence of termite activity. Termites are able to translocate particles from subsurface layers to surface layers of the soil (KASCHUK et al., 2006; SARCINELLI et al., 2013). Therefore, there can be variations between different sections of a mound, and among different mounds, between mounds, and in the soil layers at different depths. The hypotheses tested were as follows: (1) there is a difference between the material used to form termite mounds in central, top and bottom sections, and the surrounding soil, that has not been affected by the organisms, with respect to particle size and soil properties; (2) there is a difference, when comparing different types of soil management, in the influence of termites on the chemical properties of the soil.

After collection, all collected material was airdried on a laboratory workbench and sifted manually (with $2.0 \mathrm{~mm}$ mesh) to obtain fine air-dried soil (called FADS) in which the particle size analyses were performed using the pipette method (DAY, 1965), as well as chemical methods (EMBRAPA, 1997). The $\mathrm{pH}$ in water, available $\mathrm{P}$ in soil $\left(\mathrm{PO}_{4}\right.$ ), extractable acidity $(\mathrm{H}+\mathrm{Al})$, exchangeable aluminum cations $\left(\mathrm{Al}^{3+}\right)$, potassium $\left(\mathrm{K}^{+}\right)$, calcium $\left(\mathrm{Ca}^{2+}\right)$, magnesium $\left(\mathrm{Mg}^{2+}\right)$, sodium $\left(\mathrm{Na}^{+}\right)$, sum of the bases (SB), base saturation (V), cation exchange capacity (CEC), and organic carbon ( $\mathrm{C}$ org) were examined in the study.

The experimental design was completely randomized. Sections of termite nests and layers of surrounding soil were independent factors, 
whereas dependent factors included the texture and chemical properties of the soil. The results were submitted to a variance analysis test (ANOVA F), at $5 \%$ significance, to verify the homoscedasticity of waste, followed by the Tukey test at $5 \%$ significance, to compare the mean values and verify the possible influence of termite activity on the soil using the BioEstat program version 5.3 (AYRES et al., 2007). A cluster analysis was performed using the PAST program (HAMMER et al., 2001), which considered the average of the chemical attributes throughout the seasons. For each study area, a dendrogram of distances was created using a method of complete linkage and Euclidean distance.

\section{Results and Discussion}

The material used to form mounds had a higher clay content and lower sand content, regardless of the section of the mound in which it was found, when compared to the three different layers of the surrounding soil $(0-5,5-10,10-20 \mathrm{~cm})$ in the three areas studied (Figure 1). Thus, the textural type of the mound material was loamy (350 to $600 \mathrm{~g} \mathrm{~kg}^{-1}$ of clay), while the surrounding soil was considered to be average (150 to $350 \mathrm{~g} \mathrm{~kg}^{-1}$ of clay) with respect to UP, MP, and EU. Due to the higher clay content in subsurface soil layers in the three areas studied, which is a typical pattern of ultisols, it became clear that the mounds were built by termites that preferred to use material from the subsoil. Comparing the sections of the mounds, there was a trend toward greater accumulation of sand at the base and at the top, compared with the center. However, the opposite was observed for silt, which accumulated more in the center as opposed to the base and the top. These two patterns occurred in all three areas. With respect to clay, there was greater accumulation at the top and in the center, in both pasture areas, while in the eucalyptus plantation, the clay content was higher at the top and the base.

Several species of cupim select smaller particles (of clay and silt) from subsurface layers to more superficial layers to build their nests (KASCHUK et al., 2006). This causes a relative increase in their percentage values in comparison to the surrounding soil in different ecosystems, such as pasture areas, high altitude grasslands, savannah, and tropical forests (DONOVAN et al., 2001; COSARINSKY, 2011; ECHEZONA et al., 2012; SARCINELLI et al., 2013). Clay, when ingested together with the organic matter from soil or litter and mixed with the fecal matter of termites, acts as a cementing material and provides greater cohesion and stability to the structure of termite nests (COSARINSKY, 2011), as well as increased moisture retention capacity and a better microclimate for the organism's activities within the colony (DONOVAN et al., 2001).

There was a statistically significant relationship between the factors of soil management type and termites activity for most of the chemical properties of soil that were studied, during at least one of the seasons. This was true for $\mathrm{pH}$, calcium $(\mathrm{Ca})$, and base saturation $(\mathrm{V})$ during the rainy season $(\mathrm{p}<$ 0.0001 for all properties) and the dry season ( $p$ $=0.0001, \mathrm{p}<0.0011 ; \mathrm{p}=0.0198$, respectively); organic carbon ( $\mathrm{C}$ org), extractable acidity $(\mathrm{H}+$ $\mathrm{Al}$ ), and base sum (SB) during the rainy season ( $\mathrm{p}<$ $0.0001, p=0.0070, p<0.0001$, respectively); and aluminum (Al) in the dry season $(\mathrm{p}=0.0005)$.

The findings showed that the termites changed virtually all of the chemical properties of the soil, for each of the three different types of vegetation considered. However, in general, significant differences $(p<0.05)$ were observed between the center of termite nests and the other sections, and the surrounding superficial soil $(0-5,5-10,10-20$ $\mathrm{cm})$, which did not differ with regard to chemical properties in UP, MP, and EU in both seasons (Tables 1 to 4). This is because the center of the mounds had higher organic carbon values ( $\mathrm{C}$ org) which, together with higher clay content, led to higher values of cation exchange capacity (CEC) in this section, as compared with other sections of termite nests and the three layers of surrounding soil. 
Cornitermes cumulans mounds (top; base; center) and surrounding soil $(0-5 ; 5-10 ; 10-20 \mathrm{~cm})$ in areas of unmanaged degraded pasture, managed pasture, and eucalyptus plantation. Mean values \pm standard deviation.
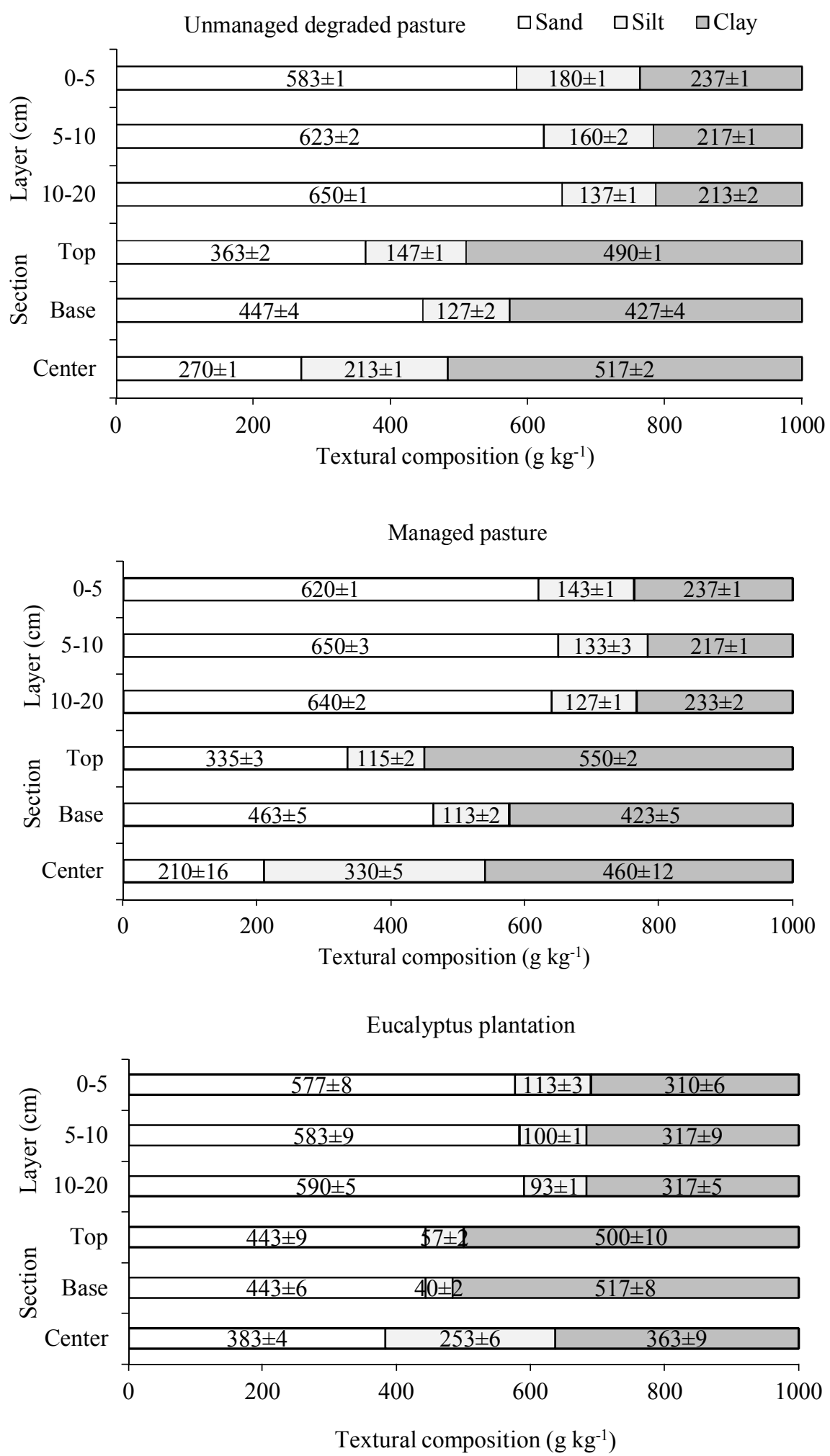
Table 1. Mean values* of $\mathrm{pH}$, exchangeable $\mathrm{Al}, \mathrm{H}+\mathrm{Al}$, organic carbon $(\mathrm{C}$ org $)$, and available phosphorus $(\mathrm{P})$ of $\mathrm{CEC}$ (cation exchangeable capacity) surrounding soil $(0-5 ; 5-10 ; 10-20 \mathrm{~cm})$ and termite nest material (top; base; center), in unmanaged degraded pasture (UP), managed pasture (MP), and eucalyptus plantation (EU) in the rainy season.

\begin{tabular}{|c|c|c|c|c|c|c|c|}
\hline \multirow{3}{*}{ Area } & \multirow{3}{*}{$\begin{array}{l}\text { Layer/ } \\
\text { Section }\end{array}$} & $\mathrm{pH}$ & $\mathrm{Al}$ & $\mathrm{H}+\mathrm{Al}$ & CEC & $\mathrm{C}$ org & $\mathrm{P}$ \\
\hline & & $\mathrm{H}_{2} \mathrm{O}$ & \multicolumn{3}{|c|}{--------cmol $\mathrm{dm}^{-3}$-------- } & $\mathrm{g} \mathrm{kg}^{-1}$ & $\mathrm{mg} \mathrm{dm}^{-3}$ \\
\hline & & \multicolumn{6}{|c|}{ Rainy } \\
\hline \multirow[t]{6}{*}{ UP } & $0-5$ & $\begin{array}{l}5.36 \mathrm{aA} \\
(0.12)\end{array}$ & $\begin{array}{c}0.16 \mathrm{aA} \\
(0.11)\end{array}$ & $\begin{array}{c}4.41 \mathrm{aAB} \\
(1.88)\end{array}$ & $\begin{array}{c}10.49 \mathrm{aA} \\
(2.12)\end{array}$ & $\begin{array}{l}5.20 \mathrm{aA} \\
(2.51)\end{array}$ & $\begin{array}{c}3.20 \mathrm{aA} \\
(0.91)\end{array}$ \\
\hline & $5-10$ & $\begin{array}{c}5.29 \mathrm{aA} \\
(0.04)\end{array}$ & $\begin{array}{c}0.26 \mathrm{aA} \\
(0.10)\end{array}$ & $\begin{array}{c}3.59 \mathrm{aA} \\
(0.82)\end{array}$ & $\begin{array}{l}8.77 \mathrm{aA} \\
(0.85)\end{array}$ & $\begin{array}{c}3.40 \mathrm{aA} \\
(0.42)\end{array}$ & $\begin{array}{c}2.40 \mathrm{aA} \\
(0.65)\end{array}$ \\
\hline & $10-20$ & $\begin{array}{c}5.19 \mathrm{aA} \\
(0.16)\end{array}$ & $\begin{array}{c}0.34 \mathrm{a} A \\
(0.13)\end{array}$ & $\begin{array}{c}3.98 \mathrm{aA} \\
(0.88)\end{array}$ & $\begin{array}{l}8.90 \mathrm{aA} \\
(0.31)\end{array}$ & $\begin{array}{c}3.10 \mathrm{aA} \\
(0.96)\end{array}$ & $\begin{array}{c}1.80 \mathrm{aA} \\
(0.27)\end{array}$ \\
\hline & Top & $\begin{array}{c}5.84 \mathrm{bA} \\
(0.23)\end{array}$ & $\begin{array}{l}0.11 \mathrm{aA} \\
(0.04)\end{array}$ & $\begin{array}{c}3.78 \mathrm{aA} \\
(0.85)\end{array}$ & $\begin{array}{c}12.88 \mathrm{aAB} \\
(1.95)\end{array}$ & $\begin{array}{c}9.40 \mathrm{aA} \\
(2.86)\end{array}$ & $\begin{array}{c}14.90 \mathrm{aA} \\
(11.83)\end{array}$ \\
\hline & Base & $\begin{array}{c}5.25 \mathrm{aA} \\
(0.13)\end{array}$ & $\begin{array}{c}0.13 \mathrm{aAB} \\
(0.03)\end{array}$ & $\begin{array}{c}5.23 \mathrm{aA} \\
(1.08)\end{array}$ & $\begin{array}{c}14.62 \mathrm{aAB} \\
(2.10)\end{array}$ & $\begin{array}{c}10.60 \mathrm{aA} \\
(2.07)\end{array}$ & $\begin{array}{c}10.70 \mathrm{aA} \\
(12.44)\end{array}$ \\
\hline & Center & $\begin{array}{c}5.44 \mathrm{aA} \\
(0.17)\end{array}$ & $\begin{array}{c}0.37 \mathrm{aA} \\
(0.22)\end{array}$ & $\begin{array}{c}14.40 \mathrm{bA} \\
(6.83)\end{array}$ & $\begin{array}{c}37.25 \mathrm{bA} \\
(13.07)\end{array}$ & $\begin{array}{c}64.70 \mathrm{bA} \\
(37.98)\end{array}$ & $\begin{array}{c}19.00 \mathrm{aA} \\
(13.82)\end{array}$ \\
\hline \multirow[t]{6}{*}{ MP } & $0-5$ & $\begin{array}{l}5.56 \mathrm{aA} \\
(0.27)\end{array}$ & $\begin{array}{c}0.04 \mathrm{aA} \\
(0.09)\end{array}$ & $\begin{array}{c}2.27 \mathrm{aB} \\
(0.45)\end{array}$ & $\begin{array}{l}9.96 \mathrm{aA} \\
(2.14)\end{array}$ & $\begin{array}{l}5.90 \mathrm{aAA} \\
(2.13)\end{array}$ & $\begin{array}{l}4.30 \mathrm{aAA} \\
(2.05)\end{array}$ \\
\hline & $5-10$ & $\begin{array}{c}5.54 \mathrm{aA} \\
(0.29)\end{array}$ & $\begin{array}{c}0.12 \mathrm{aA} \\
(0.17)\end{array}$ & $\begin{array}{c}2.46 \mathrm{aA} \\
(0.35)\end{array}$ & $\begin{array}{c}12.03 \mathrm{aA} \\
(4.09)\end{array}$ & $\begin{array}{l}4.50 \mathrm{aA} \\
(1.50)\end{array}$ & $\begin{array}{c}2.20 \mathrm{aA} \\
(0.45)\end{array}$ \\
\hline & $10-20$ & $\begin{array}{c}5.53 \mathrm{aAA} \\
(0.42)\end{array}$ & $\begin{array}{c}0.08 \mathrm{aA} \\
(0.09)\end{array}$ & $\begin{array}{c}2.25 \mathrm{aB} \\
(0.36)\end{array}$ & $\begin{array}{l}8.69 \mathrm{aA} \\
(1.21)\end{array}$ & $\begin{array}{c}4.20 \mathrm{aA} \\
(1.48)\end{array}$ & $\begin{array}{l}2.10 \mathrm{aAA} \\
(0.22)\end{array}$ \\
\hline & Topo & $\begin{array}{c}5.87 \mathrm{aA} \\
(0.41)\end{array}$ & $\begin{array}{c}0.05 \mathrm{aA} \\
(0.07)\end{array}$ & $\begin{array}{c}3.42 \mathrm{aAA} \\
(0.74)\end{array}$ & $\begin{array}{c}11.62 \mathrm{aA} \\
(1.35)\end{array}$ & $\begin{array}{l}8.70 \mathrm{aAA} \\
(3.90)\end{array}$ & $\begin{array}{l}5.20 \mathrm{aA} \\
(1.44)\end{array}$ \\
\hline & Base & $\begin{array}{c}5.53 \mathrm{aAA} \\
(0.32)\end{array}$ & $\begin{array}{c}0.08 \mathrm{aA} \\
(0.10)\end{array}$ & $\begin{array}{c}3.14 \mathrm{aAA} \\
(0.69)\end{array}$ & $\begin{array}{c}12.44 \mathrm{aA} \\
(0.54)\end{array}$ & $\begin{array}{l}9.30 \mathrm{aA} \\
(3.77)\end{array}$ & $\begin{array}{l}5.60 \mathrm{aA} \\
(3.86)\end{array}$ \\
\hline & Centro & $\begin{array}{c}5.37 \mathrm{aA} \\
(0.13)\end{array}$ & $\begin{array}{c}0.31 \mathrm{aA} \\
(0.14)\end{array}$ & $\begin{array}{c}15.50 \mathrm{bA} \\
(4.19)\end{array}$ & $\begin{array}{c}36.54 \mathrm{bA} \\
(2.70)\end{array}$ & $\begin{array}{c}125.80 \mathrm{bB} \\
(13.05)\end{array}$ & $\begin{array}{c}27.40 \mathrm{bA} \\
(21.75)\end{array}$ \\
\hline \multirow[t]{6}{*}{ EU } & $0-5$ & $\begin{array}{l}4.92 \mathrm{aB} \\
(0.20)\end{array}$ & $\begin{array}{l}0.81 \mathrm{aB} \\
(0.39)\end{array}$ & $\begin{array}{l}5.20 \mathrm{aA} \\
(1.19)\end{array}$ & $\begin{array}{c}10.90 \mathrm{aA} \\
(0.77)\end{array}$ & $\begin{array}{l}7.70 \mathrm{aA} \\
(3.62)\end{array}$ & $\begin{array}{l}5.20 \mathrm{aA} \\
(1.44)\end{array}$ \\
\hline & $5-10$ & $\begin{array}{l}4.72 \mathrm{aB} \\
(0.23)\end{array}$ & $\begin{array}{l}1.55 \mathrm{aB} \\
(0.76)\end{array}$ & $\begin{array}{l}5.43 \mathrm{aB} \\
(1.60)\end{array}$ & $\begin{array}{c}11.13 \mathrm{aA} \\
(1.94)\end{array}$ & $\begin{array}{c}3.60 \mathrm{aA} \\
(0.42)\end{array}$ & $\begin{array}{l}3.30 \mathrm{aA} \\
(0.45)\end{array}$ \\
\hline & $10-20$ & $\begin{array}{l}4.66 \mathrm{aB} \\
(0.10)\end{array}$ & $\begin{array}{l}1.61 \mathrm{aB} \\
(1.12)\end{array}$ & $\begin{array}{c}5.77 \mathrm{abC} \\
(1.06)\end{array}$ & $\begin{array}{c}11.14 \mathrm{aB} \\
(1.38)\end{array}$ & $\begin{array}{c}2.90 \mathrm{aA} \\
(0.55)\end{array}$ & $\begin{array}{c}2.70 \mathrm{aA} \\
(0.27)\end{array}$ \\
\hline & Top & $\begin{array}{c}4.84 \mathrm{aB} \\
(0.16)\end{array}$ & $\begin{array}{c}1.30 \mathrm{aA} \\
(1.42)\end{array}$ & $\begin{array}{c}\text { 7.97abcB } \\
(2.16)\end{array}$ & $\begin{array}{c}16.13 \mathrm{aB} \\
(2.62)\end{array}$ & $\begin{array}{c}6.30 \mathrm{aAA} \\
(3.44)\end{array}$ & $\begin{array}{c}3.90 \mathrm{aAA} \\
(2.04)\end{array}$ \\
\hline & Base & $\begin{array}{c}4.67 \mathrm{aB} \\
(0.19)\end{array}$ & $\begin{array}{c}1.71 \mathrm{aB} \\
(1.65)\end{array}$ & $\begin{array}{c}10.12 \mathrm{bcB} \\
(3.39)\end{array}$ & $\begin{array}{c}17.74 \mathrm{aB} \\
(3.91)\end{array}$ & $\begin{array}{l}8.00 \mathrm{aA} \\
(2.72)\end{array}$ & $\begin{array}{c}3.20 \mathrm{aA} \\
(1.10)\end{array}$ \\
\hline & Center & $\begin{array}{c}5.54 \mathrm{bA} \\
(0.17)\end{array}$ & $\begin{array}{c}0.57 \mathrm{aA} \\
(0.25)\end{array}$ & $\begin{array}{c}12.24 \mathrm{cA} \\
(3.60)\end{array}$ & $\begin{array}{c}42.71 \mathrm{bA} \\
(3.94)\end{array}$ & $\begin{array}{c}78.70 \mathrm{bA} \\
(29.30)\end{array}$ & $\begin{array}{c}16.80 \mathrm{bA} \\
(9.99)\end{array}$ \\
\hline
\end{tabular}

* Mean values of five repetitions (standard deviation). Means followed by the same letters (lowercase letters are used for comparisons among sections of soil and termite nests within the same area; and capital letters are used for comparisons among the UP, MP, and EU areas, within the same layer of soil or the same section of termite nests) indicate equality according to the Tukey test ( $<<0.05)$.

This pattern, which is repeated for all three areas studied, in both dry and rainy seasons, also occurred with regard to available phosphorus $(\mathrm{P})$, exchangeable calcium (Ca), and exchangeable magnesium $(\mathrm{Mg})$, whose values were higher in the center of termite nests (Tables 1 to 4). The highest $\mathrm{Ca}$ and $\mathrm{Mg}$ values were reflected in the larger SB values in the center, as compared with other sections 
of mounds and surrounding soil. However, lower $\mathrm{H}$ potassium (K; rainy season) were observed in the + Al values (for both seasons) and exchangeable central section of UP, MP, and EU mounds, in comparison to other sections and the topsoil.

Table 2. Mean values* of $\mathrm{pH}$, exchangeable $\mathrm{Al}, \mathrm{H}+\mathrm{Al}$, organic carbon $(\mathrm{C}$ org $)$, and available phosphorus (P) of $\mathrm{CEC}$ (cation exchangeable capacity) surrounding soil $(0-5 ; 5-10 ; 10-20 \mathrm{~cm})$ and termite nest material (top; base; center), in unmanaged degraded pasture (UP), managed pasture (MP), and eucalyptus plantation (EU) in the dry season.

\begin{tabular}{|c|c|c|c|c|c|c|c|}
\hline \multirow{3}{*}{ Area } & \multirow{3}{*}{$\begin{array}{l}\text { Layer/ } \\
\text { Section }\end{array}$} & $\mathrm{pH}$ & $\mathrm{Al}$ & & CEC & $\mathrm{C}$ org & $\mathrm{P}$ \\
\hline & & $\mathrm{H}_{2} \mathrm{O}$ & \multicolumn{3}{|c|}{--------cmol $\mathrm{dm}^{-3}$-------- } & $\mathrm{g} \mathrm{kg}^{-1}$ & $\mathrm{mg} \mathrm{dm}^{-3}$ \\
\hline & & \multicolumn{6}{|c|}{ Dry } \\
\hline \multirow[t]{6}{*}{ UP } & $0-5$ & $\begin{array}{c}5.23 \mathrm{abA} \\
(0.22)\end{array}$ & $\begin{array}{c}0.36 \mathrm{abA} \\
(0.18)\end{array}$ & $\begin{array}{l}3.20 \mathrm{aA} \\
(0.22)\end{array}$ & $\begin{array}{c}11.41 \mathrm{aA} \\
(4.68)\end{array}$ & $\begin{array}{l}5.70 \mathrm{aA} \\
(1.99)\end{array}$ & $\begin{array}{c}2.70 \mathrm{aA} \\
(0.57)\end{array}$ \\
\hline & $5-10$ & $\begin{array}{l}5.11 \mathrm{aA} \\
(0.24)\end{array}$ & $\begin{array}{c}0.46 \mathrm{bA} \\
(0.15)\end{array}$ & $\begin{array}{l}2.88 \mathrm{aA} \\
(0.39)\end{array}$ & $\begin{array}{c}9.24 \mathrm{aAB} \\
(1.11)\end{array}$ & $\begin{array}{c}5.60 \mathrm{aA} \\
(1.88)\end{array}$ & $\begin{array}{c}2.40 \mathrm{aA} \\
(0.65)\end{array}$ \\
\hline & $10-20$ & $\begin{array}{l}5.12 \mathrm{~A} \\
(0.22)\end{array}$ & $\begin{array}{c}0.50 \mathrm{bA} \\
(0.18)\end{array}$ & $\begin{array}{c}3.37 \mathrm{aA} \\
(0.67)\end{array}$ & $\begin{array}{c}8.64 \mathrm{aAB} \\
(0.59)\end{array}$ & $\begin{array}{l}4.90 \mathrm{aA} \\
(1.85)\end{array}$ & $\begin{array}{c}2.00 \mathrm{aA} \\
(1.00)\end{array}$ \\
\hline & Top & $\begin{array}{c}5.58 \mathrm{bA} \\
(0.17)\end{array}$ & $\begin{array}{l}0.09 \mathrm{aA} \\
(0.02)\end{array}$ & $\begin{array}{l}4.01 \mathrm{aA} \\
(0.58)\end{array}$ & $\begin{array}{c}13.98 \mathrm{aA} \\
(1.04)\end{array}$ & $\begin{array}{c}13.50 \mathrm{aA} \\
(1.06)\end{array}$ & $\begin{array}{c}5.70 \mathrm{aA} \\
(4.64)\end{array}$ \\
\hline & Base & $\begin{array}{c}5.22 \mathrm{abA} \\
(0.14)\end{array}$ & $\begin{array}{c}0.23 \mathrm{abA} \\
(0.18)\end{array}$ & $\begin{array}{c}4.27 \mathrm{aAB} \\
(0.39)\end{array}$ & $\begin{array}{c}18.39 \mathrm{aA} \\
(7.04)\end{array}$ & $\begin{array}{c}13.10 \mathrm{aA} \\
(1.85)\end{array}$ & $\begin{array}{c}2.70 \mathrm{aA} \\
(1.40)\end{array}$ \\
\hline & Center & $\begin{array}{c}5.37 \mathrm{abA} \\
(0.13)\end{array}$ & $\begin{array}{c}0.50 \mathrm{bA} \\
(0.15)\end{array}$ & $\begin{array}{c}15.22 \mathrm{bA} \\
(3.66)\end{array}$ & $\begin{array}{c}40.77 \mathrm{bAB} \\
(5.98)\end{array}$ & $\begin{array}{c}73.90 \mathrm{bA} \\
(12.71)\end{array}$ & $\begin{array}{c}20.20 \mathrm{bA} \\
(11.29)\end{array}$ \\
\hline \multirow[t]{6}{*}{ MP } & $0-5$ & $\begin{array}{c}5.85 \mathrm{aB} \\
(0.20)\end{array}$ & $\begin{array}{l}0.10 \mathrm{aAA} \\
(0.10)\end{array}$ & $\begin{array}{l}1.71 \mathrm{aB} \\
(0.60)\end{array}$ & $\begin{array}{l}6.83 \mathrm{aAA} \\
(1.00)\end{array}$ & $\begin{array}{l}6.20 \mathrm{aAA} \\
(2.56)\end{array}$ & $\begin{array}{l}6.50 \mathrm{aA} \\
(4.32)\end{array}$ \\
\hline & $5-10$ & $\begin{array}{c}\text { 5.72abB } \\
(0.40)\end{array}$ & $\begin{array}{c}0.11 \mathrm{aA} \\
(0.07)\end{array}$ & $\begin{array}{c}1.92 \mathrm{aB} \\
(0.75)\end{array}$ & $\begin{array}{c}6.76 \mathrm{aB} \\
(1.29)\end{array}$ & $\begin{array}{c}5.80 \mathrm{aA} \\
(2.39)\end{array}$ & $\begin{array}{c}2.60 \mathrm{aA} \\
(1.67)\end{array}$ \\
\hline & $10-20$ & $\begin{array}{c}5.39 \mathrm{abA} \\
(0.37)\end{array}$ & $\begin{array}{c}0.24 \mathrm{aA} \\
(0.22)\end{array}$ & $\begin{array}{c}2.04 \mathrm{aB} \\
(0.58)\end{array}$ & $\begin{array}{c}6.32 \mathrm{aB} \\
(1.15)\end{array}$ & $\begin{array}{l}4.40 \mathrm{aA} \\
(3.19)\end{array}$ & $\begin{array}{c}2.20 \mathrm{aA} \\
(0.84)\end{array}$ \\
\hline & Top & $\begin{array}{c}5.60 \mathrm{abA} \\
(0.20)\end{array}$ & $\begin{array}{c}0.14 \mathrm{aA} \\
(0.11)\end{array}$ & $\begin{array}{c}2.93 \mathrm{aA} \\
(0.71)\end{array}$ & $\begin{array}{c}10.62 \mathrm{aA} \\
(1.03)\end{array}$ & $\begin{array}{l}9.50 \mathrm{aA} \\
(4.29)\end{array}$ & $\begin{array}{c}6.20 \mathrm{aA} \\
(2.84)\end{array}$ \\
\hline & Base & $\begin{array}{c}5.22 \mathrm{bA} \\
(0.17)\end{array}$ & $\begin{array}{l}0.16 \mathrm{aA} \\
(0.09)\end{array}$ & $\begin{array}{c}3.39 \mathrm{aB} \\
(1.24)\end{array}$ & $\begin{array}{c}11.63 \mathrm{aA} \\
(2.53)\end{array}$ & $\begin{array}{c}8.80 \mathrm{aA} \\
(2.71)\end{array}$ & $\begin{array}{c}6.80 \mathrm{aA} \\
(8.79)\end{array}$ \\
\hline & Center & $\begin{array}{c}5.34 \mathrm{abA} \\
(0.13)\end{array}$ & $\begin{array}{c}0.58 \mathrm{bA} \\
(0.17)\end{array}$ & $\begin{array}{c}12.72 \mathrm{bA} \\
(4.85)\end{array}$ & $\begin{array}{c}32.39 \mathrm{bA} \\
(7.23)\end{array}$ & $\begin{array}{c}68.90 \mathrm{bA} \\
(27.29)\end{array}$ & $\begin{array}{c}72.20 \mathrm{bA} \\
(60.58)\end{array}$ \\
\hline \multirow[t]{6}{*}{ EU } & $0-5$ & $\begin{array}{c}4.62 \mathrm{abC} \\
(0.10)\end{array}$ & $\begin{array}{c}0.96 \mathrm{abB} \\
(0.31)\end{array}$ & $\begin{array}{l}4.58 \mathrm{aC} \\
(0.75)\end{array}$ & $\begin{array}{c}12.69 \mathrm{aA} \\
(3.65)\end{array}$ & $\begin{array}{l}7.40 \mathrm{aA} \\
(1.29)\end{array}$ & $\begin{array}{c}3.80 \mathrm{aA} \\
(1.52)\end{array}$ \\
\hline & $5-10$ & $\begin{array}{c}4.49 \mathrm{abC} \\
(0.11)\end{array}$ & $\begin{array}{c}1.44 \mathrm{abB} \\
(0.53)\end{array}$ & $\begin{array}{c}4.43 \mathrm{aC} \\
(0.38)\end{array}$ & $\begin{array}{c}12.36 \mathrm{aA} \\
(3.29)\end{array}$ & $\begin{array}{c}5.70 \mathrm{aA} \\
(1.44)\end{array}$ & $\begin{array}{c}2.40 \mathrm{aA} \\
(1.24)\end{array}$ \\
\hline & $10-20$ & $\begin{array}{c}4.38 \mathrm{aB} \\
(0.15)\end{array}$ & $\begin{array}{l}1.92 \mathrm{aB} \\
(0.53)\end{array}$ & $\begin{array}{l}4.04 \mathrm{aA} \\
(0.28)\end{array}$ & $\begin{array}{c}11.75 \mathrm{aA} \\
(3.90)\end{array}$ & $\begin{array}{c}4.40 \mathrm{aA} \\
(1.43)\end{array}$ & $\begin{array}{c}4.50 \mathrm{aA} \\
(6.45)\end{array}$ \\
\hline & Top & $\begin{array}{c}4.72 \mathrm{abB} \\
(0.20)\end{array}$ & $\begin{array}{c}1.28 \mathrm{abB} \\
(0.74)\end{array}$ & $\begin{array}{c}5.37 \mathrm{aB} \\
(0.72)\end{array}$ & $\begin{array}{c}17.73 \mathrm{aA} \\
(7.51)\end{array}$ & $\begin{array}{c}9.50 \mathrm{aA} \\
(2.62)\end{array}$ & $\begin{array}{c}2.10 \mathrm{aA} \\
(0.89)\end{array}$ \\
\hline & Base & $\begin{array}{c}4.55 \mathrm{abB} \\
(0.12)\end{array}$ & $\begin{array}{c}1.32 \mathrm{abB} \\
(0.55)\end{array}$ & $\begin{array}{c}5.54 \mathrm{aA} \\
(1.27)\end{array}$ & $\begin{array}{c}18.08 \mathrm{aA} \\
(9.06)\end{array}$ & $\begin{array}{l}8.80 \mathrm{aA} \\
(2.20)\end{array}$ & $\begin{array}{l}8.90 \mathrm{aA} \\
(10.47)\end{array}$ \\
\hline & Center & $\begin{array}{c}5.03 \mathrm{cB} \\
(0.11)\end{array}$ & $\begin{array}{c}0.76 \mathrm{bA} \\
(0.21)\end{array}$ & $\begin{array}{c}13.06 \mathrm{bA} \\
(2.22)\end{array}$ & $\begin{array}{c}45.83 \mathrm{bB} \\
(5.26)\end{array}$ & $\begin{array}{l}72.50 \mathrm{bA} \\
(26.40)\end{array}$ & $\begin{array}{c}26.50 \mathrm{bA} \\
(17.62)\end{array}$ \\
\hline
\end{tabular}

*Mean values of five repetitions (standard deviation). Means followed by the same letters (lowercase letters are used for comparisons among sections of soil and termite nests within the same area; and capital letters are used for comparisons among the UP, MP, and EU areas, within the same layer of soil or the same section of termite nests) indicate equality according to the Tukey test ( $\mathrm{p}<0.05)$. 
In areas of natural grassland, for five municipalities in the state of Santa Catarina, Kaschuk et al. (2006) also observed that the material used to form the center of mounds of different species of termites, including Cornitermes cumulans, showed higher values of $\mathrm{C}$ org, $\mathrm{P}, \mathrm{K}, \mathrm{Ca}$, and $\mathrm{Mg}$ in comparison to the surrounding soil and the other sections of the mounds, at the top and base. The increase of $\mathrm{C}$ org and nutrients $(\mathrm{P}, \mathrm{K}, \mathrm{Ca}$, and $\mathrm{Mg})$ in the matter that has been manipulated by termites occurs due to deposition of organic matter in the soil ingested by the organisms in the form of fecal or buccal matter, which acts as a cementing agent in the construction of mounds (SARCINELLI et al., 2013). However, larger values of $\mathrm{K}, \mathrm{Ca}$, and $\mathrm{Mg}$ in the mounds are also a function of the translocation of the mineralogically richer inorganic matter (clay) from subsurface layers, in the formation of aggregates that make up this biogenic structure, as compared with the surrounding topsoil (SARCINELLI et al., 2009).

Table 3. Mean values* of exchangeable $\mathrm{K}, \mathrm{Ca}, \mathrm{Mg}$, and $\mathrm{Na}$, sum of bases (SB), and V value \% of the surrounding soil $(0-5 ; 5-10 ; 10-20 \mathrm{~cm})$ and mound material (top; base; center), in unmanaged degraded pasture (UP), managed pasture (MP), and eucalyptus plantation (EU) in the rainy season.

\begin{tabular}{|c|c|c|c|c|c|c|c|}
\hline \multirow{3}{*}{ Area } & \multirow{3}{*}{$\begin{array}{l}\text { Layer/ } \\
\text { Section }\end{array}$} & $\mathrm{K}$ & $\mathrm{Ca}$ & $\mathrm{Mg}$ & $\mathrm{Na}$ & SB & \multirow{2}{*}{$\begin{array}{l}\mathrm{V} \\
\% \\
\end{array}$} \\
\hline & & \multicolumn{5}{|c|}{ 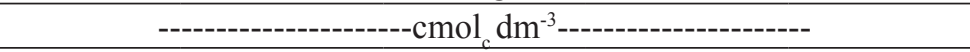 } & \\
\hline & & \multicolumn{6}{|c|}{ Rainy } \\
\hline \multirow[t]{6}{*}{ UP } & $0-5$ & $\begin{array}{c}0.36 \mathrm{abcA} \\
(0.27)\end{array}$ & $\begin{array}{c}3.34 \mathrm{aA} \\
(0.68)\end{array}$ & $\begin{array}{c}2.19 \mathrm{aAB} \\
(0.61)\end{array}$ & $\begin{array}{c}0.03 \mathrm{aA} \\
(0.00)\end{array}$ & $\begin{array}{l}5.92 \mathrm{aA} \\
(1.37)\end{array}$ & $\begin{array}{c}57.54 \mathrm{aA} \\
(10.86)\end{array}$ \\
\hline & $5-10$ & $\begin{array}{c}0.18 \mathrm{aA} \\
(0.08)\end{array}$ & $\begin{array}{c}3.31 \mathrm{aA} \\
(0.89)\end{array}$ & $\begin{array}{c}1.40 \mathrm{aA} \\
(0.61)\end{array}$ & $\begin{array}{c}0.03 \mathrm{aA} \\
(0.00)\end{array}$ & $\begin{array}{c}4.92 \mathrm{aA} \\
(0.93)\end{array}$ & $\begin{array}{c}56.41 \mathrm{aA} \\
(7.92)\end{array}$ \\
\hline & $10-20$ & $\begin{array}{c}0.13 \mathrm{aA} \\
(0.07)\end{array}$ & $\begin{array}{c}3.13 \mathrm{aA} \\
(0.59)\end{array}$ & $\begin{array}{c}1.26 \mathrm{aAB} \\
(0.66)\end{array}$ & $\begin{array}{c}0.07 \mathrm{aA} \\
(0.09)\end{array}$ & $\begin{array}{c}4.58 \mathrm{aA} \\
(0.98)\end{array}$ & $\begin{array}{c}51.30 \mathrm{aA} \\
(10.23)\end{array}$ \\
\hline & Top & $\begin{array}{c}0.47 \mathrm{bcA} \\
(0.10)\end{array}$ & $\begin{array}{c}5.07 \mathrm{aA} \\
(0.87)\end{array}$ & $\begin{array}{c}3.27 \mathrm{aA} \\
(1.37)\end{array}$ & $\begin{array}{c}0.16 \mathrm{aA} \\
(0.11)\end{array}$ & $\begin{array}{c}8.99 \mathrm{aA} \\
(2.17)\end{array}$ & $\begin{array}{c}68.66 \mathrm{aA} \\
(8.75)\end{array}$ \\
\hline & Base & $\begin{array}{c}0.33 \mathrm{abcA} \\
(0.05)\end{array}$ & $\begin{array}{l}5.24 \mathrm{aA} \\
(1.54)\end{array}$ & $\begin{array}{l}3.66 \mathrm{aA} \\
(0.55)\end{array}$ & $\begin{array}{c}0.03 \mathrm{aA} \\
(0.00)\end{array}$ & $\begin{array}{c}9.26 \mathrm{aA} \\
(2.06)\end{array}$ & $\begin{array}{c}62.76 \mathrm{aA} \\
(8.13)\end{array}$ \\
\hline & Center & $\begin{array}{c}0.62 \mathrm{cA} \\
(0.21)\end{array}$ & $\begin{array}{c}12.70 \mathrm{bA} \\
(3.90)\end{array}$ & $\begin{array}{c}9.13 \mathrm{bA} \\
(3.86)\end{array}$ & $\begin{array}{c}0.03 \mathrm{aA} \\
(0.01)\end{array}$ & $\begin{array}{c}22.48 \mathrm{bA} \\
(6.87)\end{array}$ & $\begin{array}{c}61.69 \mathrm{aA} \\
(8.31)\end{array}$ \\
\hline \multirow[t]{6}{*}{ MP } & $0-5$ & $\begin{array}{c}0.31 \mathrm{abA} \\
(0.06)\end{array}$ & $\begin{array}{c}4.43 \mathrm{aA} \\
(1.13)\end{array}$ & $\begin{array}{c}2.89 \mathrm{aA} \\
(0.99)\end{array}$ & $\begin{array}{l}0.03 \mathrm{aA} \\
(0.01)\end{array}$ & $\begin{array}{l}7.65 \mathrm{aA} \\
(1.81)\end{array}$ & $\begin{array}{c}76.64 \mathrm{aB} \\
(3.10)\end{array}$ \\
\hline & $5-10$ & $\begin{array}{c}0.17 \mathrm{abA} \\
(0.05)\end{array}$ & $\begin{array}{c}6.05 \mathrm{aA} \\
(2.78)\end{array}$ & $\begin{array}{c}3.20 \mathrm{aB} \\
(1.22)\end{array}$ & $\begin{array}{c}0.03 \mathrm{aA} \\
(0.01)\end{array}$ & $\begin{array}{c}9.45 \mathrm{aA} \\
(3.79)\end{array}$ & $\begin{array}{c}74.76 \mathrm{aB} \\
(4.57)\end{array}$ \\
\hline & $10-20$ & $\begin{array}{c}0.10 \mathrm{aA} \\
(0.02)\end{array}$ & $\begin{array}{c}3.84 \mathrm{aA} \\
(0.62)\end{array}$ & $\begin{array}{c}2.39 \mathrm{aA} \\
(0.78)\end{array}$ & $\begin{array}{l}0.04 \mathrm{aA} \\
(0.21)\end{array}$ & $\begin{array}{c}6.36 \mathrm{aA} \\
(1.21)\end{array}$ & $\begin{array}{c}72.87 \mathrm{aB} \\
(5.11)\end{array}$ \\
\hline & Top & $\begin{array}{c}0.36 \mathrm{bcA} \\
(0.03)\end{array}$ & $\begin{array}{l}5.02 \mathrm{aA} \\
(1.59)\end{array}$ & $\begin{array}{c}2.73 \mathrm{aA} \\
(0.55)\end{array}$ & $\begin{array}{l}0.04 \mathrm{aA} \\
(0.02)\end{array}$ & $\begin{array}{l}8.15 \mathrm{aA} \\
(1.08)\end{array}$ & $\begin{array}{c}\text { 69.66abA } \\
(4.74)\end{array}$ \\
\hline & Base & $\begin{array}{c}0.25 \mathrm{abA} \\
(0.07)\end{array}$ & $\begin{array}{l}5.80 \mathrm{aA} \\
(1.09)\end{array}$ & $\begin{array}{c}3.14 \mathrm{aA} \\
(0.22)\end{array}$ & $\begin{array}{c}0.03 \mathrm{aA} \\
(0.01)\end{array}$ & $\begin{array}{c}9.22 \mathrm{aA} \\
(0.96)\end{array}$ & $\begin{array}{c}73.73 \mathrm{aA} \\
(6.17)\end{array}$ \\
\hline & Center & $\begin{array}{c}0.55 \mathrm{cA} \\
(0.25)\end{array}$ & $\begin{array}{c}12.93 \mathrm{bA} \\
(3.72)\end{array}$ & $\begin{array}{l}7.55 \mathrm{bA} \\
(1.64)\end{array}$ & $\begin{array}{c}0.04 \mathrm{aA} \\
(0.02)\end{array}$ & $\begin{array}{c}20.73 \mathrm{bA} \\
(4.24)\end{array}$ & $\begin{array}{c}56.94 \mathrm{bA} \\
(12.67)\end{array}$ \\
\hline \multirow[t]{2}{*}{ EU } & $0-5$ & $\begin{array}{l}0.38 \mathrm{aAA} \\
(0.12)\end{array}$ & $\begin{array}{c}3.14 \mathrm{aA} \\
(1.25)\end{array}$ & $\begin{array}{c}1.35 \mathrm{aB} \\
(0.50)\end{array}$ & $\begin{array}{c}0.03 \mathrm{aAA} \\
(0.01)\end{array}$ & $\begin{array}{c}4.89 \mathrm{aA} \\
(1.63)\end{array}$ & $\begin{array}{c}44.95 \mathrm{aA} \\
(12.91)\end{array}$ \\
\hline & $5-10$ & $\begin{array}{c}0.28 \mathrm{aA} \\
(0.12)\end{array}$ & $\begin{array}{c}2.61 \mathrm{aA} \\
(0.96)\end{array}$ & $\begin{array}{l}1.17 \mathrm{aA} \\
(0.40)\end{array}$ & $\begin{array}{c}0.03 \mathrm{aA} \\
(0.01)\end{array}$ & $\begin{array}{c}4.09 \mathrm{aA} \\
(1.25)\end{array}$ & $\begin{array}{c}37.22 \mathrm{aC} \\
(12.67)\end{array}$ \\
\hline
\end{tabular}


continuation

\begin{tabular}{lcccccc} 
& & & & & \\
$10-20$ & $0.20 \mathrm{aA}$ & $2.63 \mathrm{aA}$ & $0.90 \mathrm{aB}$ & $0.02 \mathrm{aA}$ & $3.76 \mathrm{aA}$ & $33.87 \mathrm{aA}$ \\
& $(0.08)$ & $(1.35)$ & $(0.64)$ & $(0.01)$ & $(1.81)$ & $(14.99)$ \\
Top & $0.34 \mathrm{aA}$ & $4.28 \mathrm{aA}$ & $2.21 \mathrm{aA}$ & $0.03 \mathrm{aA}$ & $6.86 \mathrm{aA}$ & $43.75 \mathrm{aB}$ \\
& $(0.05)$ & $(1.09)$ & $(0.74)$ & $(0.01)$ & $(1.72)$ & $(12.19)$ \\
Base & $0.27 \mathrm{aA}$ & $3.45 \mathrm{aA}$ & $2.16 \mathrm{aB}$ & $0.03 \mathrm{aA}$ & $5.91 \mathrm{aA}$ & $35.49 \mathrm{aB}$ \\
& $(0.04)$ & $(1.18)$ & $(0.51)$ & $(0.01)$ & $(1.68)$ & $(7.41)$ \\
\multirow{2}{*}{ Center } & $0.72 \mathrm{bA}$ & $21.73 \mathrm{bA}$ & $7.41 \mathrm{bA}$ & $0.04 \mathrm{aA}$ & $29.90 \mathrm{bA}$ & $71.37 \mathrm{bA}$ \\
& $(0.34)$ & $(3.10)$ & $(3.78)$ & $(0.02)$ & $(4.05)$ & $(8.88)$
\end{tabular}

*Mean values of five repetitions (standard deviation). Means followed by the same letters (lowercase letters are used for comparisons among sections of soil and termite nests within the same area; and capital letters are used for comparisons among the UP, MP, and $\mathrm{EU}$ areas, within the same layer of soil or the same section of termite nests) indicate equality according to the Tukey test ( $\mathrm{p}<0.05)$.

Table 4. Mean values* of exchangeable $\mathrm{K}, \mathrm{Ca}, \mathrm{Mg}$, and $\mathrm{Na}$, sum of bases (SB), and $\mathrm{V}$ value $\%$ of the surrounding soil $(0-5 ; 5-10 ; 10-20 \mathrm{~cm})$ and mound material (top; base; center), in unmanaged degraded pasture (UP), managed pasture (MP), and eucalyptus plantations (EU) in the dry season.

\begin{tabular}{|c|c|c|c|c|c|c|c|}
\hline \multirow[b]{2}{*}{ Area } & \multirow{2}{*}{$\begin{array}{l}\text { Layer/ } \\
\text { Section }\end{array}$} & $\mathrm{K}$ & $\mathrm{Ca}$ & $\mathrm{Mg}$ & $\mathrm{Na}$ & \multirow[t]{2}{*}{ SB } & \multirow{2}{*}{$\begin{array}{l}\mathrm{V} \\
\%\end{array}$} \\
\hline & & \multicolumn{4}{|c|}{ Dry } & & \\
\hline \multirow[t]{6}{*}{ UP } & $0-5$ & $\begin{array}{c}0.23 \mathrm{aA} \\
(0.09)\end{array}$ & $\begin{array}{c}4.18 \mathrm{aA} \\
(1.55)\end{array}$ & $\begin{array}{l}3.40 \mathrm{aA} \\
(3.09)\end{array}$ & $\begin{array}{l}0.04 \mathrm{aA} \\
(0.02)\end{array}$ & $\begin{array}{l}7.85 \mathrm{aA} \\
(4.66)\end{array}$ & $\begin{array}{c}\text { 61.97abAB } \\
(4.97)\end{array}$ \\
\hline & $5-10$ & $\begin{array}{c}0.18 \mathrm{aA} \\
(0.11)\end{array}$ & $\begin{array}{l}3.61 \mathrm{aA} \\
(0.52)\end{array}$ & $\begin{array}{c}2.08 \mathrm{aA} \\
(0.44)\end{array}$ & $\begin{array}{l}0.02 \mathrm{aA} \\
(0.01)\end{array}$ & $\begin{array}{l}5.90 \mathrm{aA} \\
(0.86)\end{array}$ & $\begin{array}{c}\text { 61.18abA } \\
(4.93)\end{array}$ \\
\hline & $10-20$ & $\begin{array}{c}0.18 \mathrm{aA} \\
(0.10)\end{array}$ & $\begin{array}{l}3.36 \mathrm{aA} \\
(0.50)\end{array}$ & $\begin{array}{l}1.21 \mathrm{aA} \\
(0.27)\end{array}$ & $\begin{array}{l}0.02 \mathrm{aA} \\
(0.00)\end{array}$ & $\begin{array}{l}4.77 \mathrm{aA} \\
(0.60)\end{array}$ & $\begin{array}{c}54.25 \mathrm{bAB} \\
(6.12)\end{array}$ \\
\hline & Top & $\begin{array}{c}0.37 \mathrm{aA} \\
(0.02)\end{array}$ & $\begin{array}{l}6.09 \mathrm{aA} \\
(0.86)\end{array}$ & $\begin{array}{l}3.36 \mathrm{aA} \\
(0.95)\end{array}$ & $\begin{array}{l}0.06 \mathrm{aA} \\
(0.03)\end{array}$ & $\begin{array}{l}9.88 \mathrm{aA} \\
(0.96)\end{array}$ & $\begin{array}{c}69.60 \mathrm{aA} \\
(3.18)\end{array}$ \\
\hline & Base & $\begin{array}{l}0.31 \mathrm{aA} \\
(0.06)\end{array}$ & $\begin{array}{c}9.55 \mathrm{aA} \\
(4.87)\end{array}$ & $\begin{array}{c}3.99 \mathrm{aA} \\
(2.27)\end{array}$ & $\begin{array}{l}0.04 \mathrm{aA} \\
(0.02)\end{array}$ & $\begin{array}{c}13.89 \mathrm{aA} \\
(7.01)\end{array}$ & $\begin{array}{c}70.87 \mathrm{aA} \\
(8.87)\end{array}$ \\
\hline & Center & $\begin{array}{c}1.26 \mathrm{aA} \\
(1.76)\end{array}$ & $\begin{array}{c}15.50 \mathrm{bA} \\
(2.59)\end{array}$ & $\begin{array}{c}8.24 \mathrm{bA} \\
(3.25)\end{array}$ & $\begin{array}{c}0.05 \mathrm{aA} \\
(0.02)\end{array}$ & $\begin{array}{c}25.05 \mathrm{bAB} \\
(3.68)\end{array}$ & $\begin{array}{c}\text { 61.18abA } \\
(6.84)\end{array}$ \\
\hline \multirow[t]{6}{*}{ MP } & $0-5$ & $\begin{array}{c}0.40 \mathrm{aA} \\
(0.11)\end{array}$ & $\begin{array}{l}2.95 \mathrm{aA} \\
(0.52)\end{array}$ & $\begin{array}{l}1.63 \mathrm{aA} \\
(0.54)\end{array}$ & $\begin{array}{l}0.05 \mathrm{aA} \\
(0.03)\end{array}$ & $\begin{array}{l}5.02 \mathrm{aAA} \\
(1.04)\end{array}$ & $\begin{array}{c}74.09 \mathrm{aA} \\
(8.27)\end{array}$ \\
\hline & $5-10$ & $\begin{array}{c}0.62 \mathrm{aA} \\
(0.89)\end{array}$ & $\begin{array}{c}2.55 \mathrm{aA} \\
(1.01)\end{array}$ & $\begin{array}{c}1.52 \mathrm{aAB} \\
(0.75)\end{array}$ & $\begin{array}{l}0.03 \mathrm{aA} \\
(0.02)\end{array}$ & $\begin{array}{c}4.73 \mathrm{aA} \\
(1.23)\end{array}$ & $\begin{array}{c}70.98 \mathrm{aA} \\
(8.93)\end{array}$ \\
\hline & $10-20$ & $\begin{array}{c}0.15 \mathrm{aA} \\
(0.04)\end{array}$ & $\begin{array}{c}2.75 \mathrm{aAB} \\
(0.71)\end{array}$ & $\begin{array}{c}1.10 \mathrm{aAB} \\
(0.61)\end{array}$ & $\begin{array}{c}0.04 \mathrm{aA} \\
(0.01)\end{array}$ & $\begin{array}{l}4.04 \mathrm{aA} \\
(0.72)\end{array}$ & $\begin{array}{c}64.68 \mathrm{aA} \\
(8.15)\end{array}$ \\
\hline & Top & $\begin{array}{c}0.39 \mathrm{aA} \\
(0.11)\end{array}$ & $\begin{array}{c}4.67 \mathrm{aB} \\
(0.49)\end{array}$ & $\begin{array}{c}2.38 \mathrm{aA} \\
(0.66)\end{array}$ & $\begin{array}{l}0.11 \mathrm{aA} \\
(0.05)\end{array}$ & $\begin{array}{l}7.55 \mathrm{aA} \\
(0.56)\end{array}$ & $\begin{array}{c}70.48 \mathrm{aA} \\
(5.10)\end{array}$ \\
\hline & Base & $\begin{array}{c}0.54 \mathrm{aA} \\
(0.23)\end{array}$ & $\begin{array}{c}4.81 \mathrm{aAB} \\
(1.49)\end{array}$ & $\begin{array}{c}2.70 \mathrm{aA} \\
(1.09)\end{array}$ & $\begin{array}{l}0.03 \mathrm{aA} \\
(0.02)\end{array}$ & $\begin{array}{l}8.08 \mathrm{aA} \\
(2.42)\end{array}$ & $\begin{array}{c}69.20 \mathrm{aA} \\
(11.35)\end{array}$ \\
\hline & Center & $\begin{array}{c}1.36 \mathrm{aA} \\
(0.37)\end{array}$ & $\begin{array}{c}11.86 \mathrm{bA} \\
(2.67)\end{array}$ & $\begin{array}{c}5.82 \mathrm{bA} \\
(1.59)\end{array}$ & $\begin{array}{c}0.04 \mathrm{aA} \\
(0.02)\end{array}$ & $\begin{array}{c}19.09 \mathrm{bB} \\
(3.65)\end{array}$ & $\begin{array}{c}60.85 \mathrm{aA} \\
(11.85) \\
\end{array}$ \\
\hline \multirow[t]{2}{*}{$\mathrm{EU}$} & $0-5$ & $\begin{array}{c}2.71 \mathrm{aA} \\
(4.37)\end{array}$ & $\begin{array}{l}2.91 \mathrm{aA} \\
(1.02)\end{array}$ & $\begin{array}{l}1.46 \mathrm{aA} \\
(0.53)\end{array}$ & $\begin{array}{c}0.07 \mathrm{aA} \\
(0.08)\end{array}$ & $\begin{array}{l}7.15 \mathrm{aA} \\
(4.24)\end{array}$ & $\begin{array}{c}51.45 \mathrm{abB} \\
(13.29)\end{array}$ \\
\hline & $5-10$ & $\begin{array}{c}3.07 \mathrm{aA} \\
(4.18)\end{array}$ & $\begin{array}{c}2.34 \mathrm{aA} \\
(0.93)\end{array}$ & $\begin{array}{c}0.99 \mathrm{aB} \\
(0.39)\end{array}$ & $\begin{array}{c}0.09 \mathrm{aA} \\
(0.08)\end{array}$ & $\begin{array}{l}6.49 \mathrm{aA} \\
(3.33)\end{array}$ & $\begin{array}{c}47.28 \mathrm{abB} \\
(5.74)\end{array}$ \\
\hline
\end{tabular}


continuation

\begin{tabular}{lcccccc} 
& $2.60 \mathrm{aA}$ & $2.02 \mathrm{aB}$ & $1.05 \mathrm{aB}$ & $0.12 \mathrm{aB}$ & $5.79 \mathrm{aA}$ & $42.65 \mathrm{aB}$ \\
& $(4.38)$ & $(0.72)$ & $(0.56)$ & $(0.06)$ & $(4.02)$ & $(12.25)$ \\
Top & $4.74 \mathrm{aA}$ & $3.83 \mathrm{aB}$ & $2.42 \mathrm{aA}$ & $0.09 \mathrm{aA}$ & $11.08 \mathrm{aA}$ & $54.98 \mathrm{abB}$ \\
& $(8.79)$ & $(0.71)$ & $(0.95)$ & $(0.08)$ & $(8.35)$ & $(13.13)$ \\
\multirow{2}{*}{ Base } & $5.17 \mathrm{aA}$ & $3.67 \mathrm{aB}$ & $2.30 \mathrm{aA}$ & $0.08 \mathrm{aA}$ & $11.22 \mathrm{aA}$ & $54.98 \mathrm{abA}$ \\
& $(8.71)$ & $(0.67)$ & $(0.47)$ & $(0.10)$ & $(8.31)$ & $(10.28)$ \\
\multirow{2}{*}{ Center } & $6.28 \mathrm{aA}$ & $18.55 \mathrm{bA}$ & $7.06 \mathrm{bA}$ & $0.12 \mathrm{aB}$ & $32.01 \mathrm{bA}$ & $66.41 \mathrm{bA}$ \\
& $(9.45)$ & $(6.00)$ & $(2.76)$ & $(0.05)$ & $(7.25)$ & $(7.35)$
\end{tabular}

*Mean values of five repetitions (standard deviation). Means followed by the same letters (lowercase letters are used for comparisons among sections of soil and termite nests within the same area; and capital letters are used for comparisons among the UP, MP, and EU areas, within the same layer of soil or the same section of termite nests) indicate equality according to the Tukey test ( $<<0.05)$.

In this study, we expected to find higher $\mathrm{H}+\mathrm{Al}$ values at the center of termite nests, since soil rich in organic matter generally exhibits high values of this variable, and since this condition basically depends on high $\mathrm{H}^{+}$values, which are derived from organic compounds and from the hydrolysis of sulfur-rich substances (EBELING et al., 2008). In both seasons, $\mathrm{pH}$ values were higher in the center of the mound only in the EU area, as compared with other sections of the mounds and layers of surrounding soil. Values did not differ from those recorded in the two pasture areas (Tables 1 and 4). Comparing the layers of surrounding soil with sections of termite nests in the three areas studied, we did not observe significant differences $(p<0.05)$ in values of exchangeable sodium $(\mathrm{Na})$, and there was no clear pattern of response with respect to the $\mathrm{Al}$ and $\mathrm{V}$ values during the rainy and dry seasons.

Comparing the three areas studied, we observed three patterns of results for the chemical properties examined. The values of $\mathrm{pH}, \mathrm{Mg}$, and $\mathrm{V}$ (for both seasons) and $\mathrm{Ca}$ (for the dry season) were lower in the surrounding soil and termite nests in the Corymbia citriodora eucalyptus plantation (EU), as compared with at least one of the pasture areas (Tables 1 to 4). The values of $\mathrm{Na}$ (in the dry season), and $\mathrm{Al}, \mathrm{H}+\mathrm{Al}$, and $\mathrm{CEC}$ (during both seasons) were higher in the EU area, when compared with at least one of the pasture areas.

These results corroborate those found in other studies, in which the topsoil found in Corymbia citriodora plantations and hybrid Eucalyptus urophylla $\mathrm{x}$ Eucalyptus grandis areas also had lower $\mathrm{pH}, \mathrm{Ca}$, and $\mathrm{V}$, but higher $\mathrm{Al}$ and $\mathrm{CEC}$ values, as compared to pasture areas (GAMA-RODRIGUES et al., 2008; EFFGEN et al., 2012). This is due to differences among different types of soil management in relation to the nature of the organic matter found in the soil and the resulting structural stability and stage of decomposition of that matter (LIMA et al., 2008; PINHEIRO et al., 2013), which influences not only the $\mathrm{pH}$ but also the availability of nutrients in the soil for plants.

No differences were observed among the areas of the present study with respect to values of $\mathrm{C}$ org, $\mathrm{K}, \mathrm{P}$, and $\mathrm{SB}$ in the layers of surrounding soil $(0-5,5-10,10-20 \mathrm{~cm})$ and the mounds (top, base, and center), taking both seasons into consideration (Tables 1 to 4). When compared with $\mathrm{Na}$, no difference was found in relation to the value of $\mathrm{K}$, and the results of $\mathrm{Ca}$ and $\mathrm{Mg}$ diverged; this resulted in all three areas being similar with regard to SB. The relatively small amounts of $\mathrm{Ca}$ and $\mathrm{Mg}$ were responsible for the lower values of $\mathrm{V}$ in the EU area. In this area, the lower $\mathrm{pH}$ values were influenced by higher values of extractable acidity. The CEC is dependent on $\mathrm{K}$, which did not differ when compared within the three areas. It is also dependent on $\mathrm{Ca}$ and $\mathrm{Mg}$, which were lower in the soil in the $\mathrm{EU}$ area, as well as on $\mathrm{H}+\mathrm{Al}$, which were higher in that area. The high levels of extractable acidity were consequently responsible for the greater CEC 
in the soil of eucalyptus plantations. In some cases, comparison between sections of termite nests and layers of soil showed that the absence of significant differences $(p<0.05)$, in relation to the average values of the chemical attributes, was influenced by the high variability of the data found over various replications, which is evidenced by the high standard deviation values, as reported in the tables.

The cluster analysis showed that the sections of the top and base correlated to a mean distance of less than $10 \%$, which was also verified by the correlation of the three soil layers adjacent to each other in UP, MP, and EU (Figure 2). These two groups (top and base, and three adjoining surface layers of soil) correlated well with each other at a small distance (less than 20\%). However, the central section correlated with the other sections of termite nests and layers of surrounding soil at a greater distance, between $75 \%$ and $108 \%$.

This pattern reflected the difference in composition of the central section, with its higher levels of organic matter and its isolated position, in relation to the other sections of the mounds, and the layers of surrounding soil, which contributed more mineral material. According to field observations in pasture areas, it was found that grasses located around the mounds showed more vigorous growth.

Figure 2. Dendrogram of distance obtained by averaging the seasons (dry and wet) by the chemical attributes of termite nests (Top, Base, and Center sections) and the surrounding soil $(05,10$, and 20: 0-5; 5-10; 10-20 cm, respectively), in unmanaged degraded pasture, managed pasture, and eucalyptus plantation.
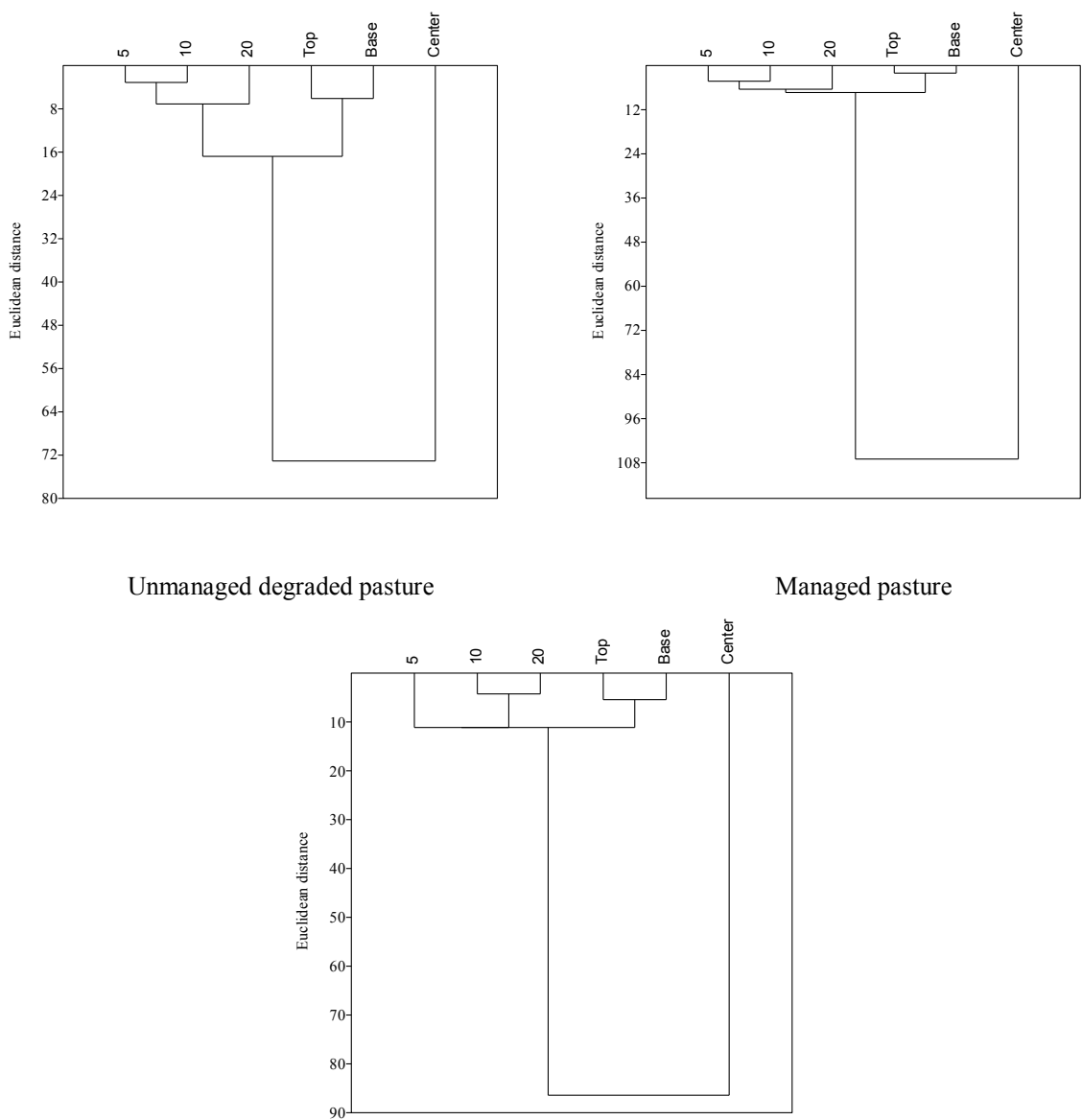

Eucalyptus plantations 
There is more organic matter in the soil, especially humin, which promotes microbial activity, in the central section of the Cornitermes cumulans mounds, compared with other sections of the mounds and surrounding soil (PINHEIRO et al., 2013). Therefore, the amount of organic matter in mounds, especially in the central section, seems to correlate with the soil nutrient availability for plants. These results emphasize the important role of termites in minimizing the degradation of chemical conditions of the soil in pasture areas and eucalyptus plantations, which is accelerated in the "Mar de Morros" environment due to climatic conditions, topography, and low natural fertility of the soil.

\section{Conclusions}

Termite activity involves the selection of fine soil particles and alters the majority of chemical properties of the soil at the center sections of termite nests, as compared with the other sections (top and base) and the topsoil (0-5, 5-10, 10-20 cm) in the three areas studied (unmanaged degraded pasture, managed pasture, and a Corymbia citriodora eucalyptus plantation), in the region of Pinheiral, Rio de Janiero.

The influence of termites on most soil chemical properties differed in the Corymbia citriodora eucalyptus plantation, when compared with degraded managed pasture and managed pasture areas, which did not differ from each other.

\section{References}

AB'SABER, A. Domínios morfoclimáticos e solos do Brasil. In: ALVAREZ, V. V. H.; FONTES, L. E. F.; FONTES, M. P. F. (Ed.). Os solos nos grandes domínios morfoclimáticos do Brasil e o desenvolvimento sustentável. Viçosa, MG: Sociedade Brasileira de Ciência do Solo/Universidade Federal de Viçosa, 1996. p. 1-18.

ACKERMAN, I. L.; TEIXEIRA, W. G.; RIHA, S. J.; LEHMANN, J.; FERNANDES, E. C. M. The impact of mound-building termites on surface soil properties in a secondary forest of Central Amazonia. Applied Soil Ecology, Amsterdan, v. 37, n. 3, p. 267-276, 2007.

AQUiNO, A. M.; CORREIA, M. E. F.; ALVES, M. V. Diversidade da macrofauna edáfica no Brasil. In: MOREIRA, F. M. S.; SIQUEIRA, J. O.; BRUSSAARD, L. (Ed.). Biodiversidade do solo em ecossistemas brasileiros. Lavras: Universidade Federal de Lavras, 2008. p. 143-170.

AYRES, M.; AYRES JÚNIOR, M.; AYRES, D. L.; SANTOS, A. S. BioEstat 5.0: aplicações estatísticas nas áreas das ciências biológicas e médicas. 5. ed. Belém: Instituto de Desenvolvimento Sustentável Mamirauá, 2007. 380 p.

BENITO, N. P.; BROSSARD, M.; PASINI, A.; GUIMARÃES, M. F.; BOBILLIER, B. Transformations of soil macroinvertebrate populations after native vegetation conversion to pasture cultivation (Brazilian Cerrado). European Journal of Soil Biology, Paris, v. 40, n. 3-4, p. 147-154, 2004.

COSARINSKY, M. I. The nest growth of the Neotropical mound-building termite, Cornitermes cumulans: a micromorphological analysis. Journal of Insect Science, Oxford, v. 11, n. 122, p. 1-14, 2011.

DANGERFIELD, J. M.; MCCARTHY, T. S.; ELLERY, W. N. The mound-building termite Macrotermes michaelseni as an ecosystem engineer. Journal of Tropical Ecology, Cambridge, v. 14, n. 4, p. 507-520, 1998.

DAY, P. R. Particle fractionation and particle-size analysis. In: BLACK, C. A. (Ed.). Methods of soil analysis. Madison: American Society of Agronomy, 1965. p. 545-566.

DONOVAN, S. E.; EGGLETON, P.; DUBBIN, W. E.; BATCHELDER, M.; DIBOG, L. The effect of a soil-feeding termite, Cubitermes fungifaber (Isoptera: Termitidae) on soil properties: termites may be an important source of soil microhabitat heterogeneity in tropical forests. Pedobiologia, Jena, v. 45, n. 1, p. 1-11, 2001.

EBElinG, A. G.; ANJOS, L. H. C.; PEREZ, D. V.; PEREIRA, M. G.; VALLADARES, G. S. Relação entre acidez e outros atributos químicos em solos com teores elevados de matéria orgânica. Bragantia, Campinas, v. 67, n. 2, p. 429-439, 2008.

EChezonA, B. C.; IGWE, C. A.; ATtama, L. A. Properties of arboreal ant and ground-termite nests in relation to their nesting sites and location in a Tropicalderived Savanna. Psyche, Cambridge, v. 2012, Article ID 235840, p. 1-11, 2012. 
EFFGEN, E. M.; NAPPO, M. E.; CECÍLIO, R. A.; MENDONÇA, A. R.; MANZOLE, R.; BORCARTE, M. Atributos químicos de um latossolo Vermelho-Amarelo distrófico sob cultivo de eucalipto e pastagem no sul do Espírito Santo. Scientia Forestalis, Piracicaba, v. 40, n. 95, p. 375-381, 2012.

\section{EMPRESA BRASILEIRA DE PESQUISA} AGROPECUÁRIA - EMBRAPA. Manual de métodos de análises de solo. 2. ed. Rio de Janeiro: Centro Nacional de Pesquisa de Solos, 1997. 212 p.

FERNANDES, P. M.; CZEPAK, C.; VELOSO, V. R. S. Cupins de montículos em pastagens: prejuízo real ou praga estética? In: FONTES, L. R.; BERTI FILHO, E. (Ed.). Cupins: o desafio do conhecimento. Piracicaba: FEALQ, 1998. p. 187-210.

FERREIRA, E. V. O.; MARTINS, V.; INDA JUNIOR, A. V.; GIASSON, E.; NASCIMENTO, P. C. Ação dos térmitas no solo. Ciência Rural, Santa Maria, v. 41, n. 5, p. 804-811, 2011.

GAMA-RODRIGUES, E. M.; GAMA-RODRIGUES, A. C.; PAUlinO, G. M.; FRANCO, A. A. Atributos químicos e microbianos de solos sob diferentes coberturas vegetais no norte do Estado do Rio de Janeiro. Revista Brasileira de Ciência do Solo, Viçosa, MG, v. 32, n. 4, p. 1521-1530, 2008.

HAMMER, O.; HARPER, D. A.; RYAN, P. D. PAST: Paleontological statistics software package for education and data analysis. Palaeontologia Electronica, California, v. 4, p. 1-9, 2001. Available at: $<$ http://palaeo-electronica. org/2001_1/past/issue1_01.htm>. Acessed on: 14 Apr. 2015.

JOUQUET, P.; BLANCHART, E.; CAPOWIEZ, Y. Utilization of earthworms and termites for the restoration of ecosystem functioning. Applied Soil Ecology, Amsterdan, v. 73, p. 34-40, 2014.

KASCHUK, G.; SANTOS, J. C. P.; ALMEIDA, J. A.; SINHORATI, D. C.; BERTON-JUNIOR, J. F. Termite activity in relation to natural grassland soil attributes. Scientia Agricola, Piracicaba, v. 63, n. 6, p. 583-588, 2006.

KÖPPEN, W. Climatologia: con un estudio de los climas de la tierra. Ciudad de Mexico: Fondo de Cultura Econômica, 1948. 488 p.

LIMA, A. M. N.; SILVA, I. R.; NEVES, J. C. L.; NOVAIS, R. F.; BARROS, N. F.; MENDONÇA, E. S.; DEMOLINARI, M. S. M.; LEITE, F. P. Frações da matéria orgânica do solo após três décadas de cultivo de eucalipto no Vale do Rio Doce-MG. Revista Brasileira de Ciência do Solo, Viçosa, MG, v. 32, n. 3, p. 10531063, 2008.
PINHEIRO, L. B. A.; PEREIRA, M. G. P.; LIMA, E.; CORREIA, M. E. F.; SILVA, C. F.; EBELING, A. G. Atributos edáficos e de termiteiros de cupim-demontículo (Isoptera: Termitidae) em Pinheiral-RJ. Floresta \& Ambiente, Seropédica, v. 20, n. 4, p. 510-520, 2013.

REDFORD, K. H. The termitaria of Cornitermes cumulans (Isoptera, Termitidae) and their role in determining a potential keystone species. Biotropica, Florida, v. 16, n. 2, p. 112-119, 1984.

SANTOS, H. G.; JACOMINE, P. K. T.; ANJOS, L. H. C.; OLIVEIRA, V. A.; LUMBRERAS, J. F.; COELHO, M. R.; ALMEIDA, J. A.; CUNHA, T. J. F.; OLIVEIRA, J. B. Sistema brasileiro de classificação de solos. 3. ed. Brasília: EMBRAPA, 2013. 353 p.

SARCINELLI, T. S.; SCHAEFER, C. E. G. R.; FERNANDES FILHO, E. I.; MAFIA, R. G.; NERI, A. V. Soil modification by termites in a sandy-soil vegetation in the Brazilian Atlantic rain forest. Journal of Tropical Ecology, Cambridge, v. 29, n. 5, p. 439-448, 2013.

SARCINELLI, T. S.; SCHAEFER, C. E. G. R.; LYNCH, L. S.;ARATO, H. D.; VIANA, J.H. M.; ALBUQUERQUE FILHO, M. R.; GONÇALVES, T. T. Chemical, physical and micromorphological properties of termite mounds and adjacent soils along a toposequence in Zona da Mata, Minas Gerais State, Brazil. Catena, Amsterdan, v. 76, n. 2, p. 107-113, 2009.

SILVA, R. F.; AQUINO, A. M.; MERCANTE, F. M.; GUIMARÃES, M. F. Macrofauna invertebrada do solo sob diferentes sistemas de produção em Latossolo da Região do Cerrado. Pesquisa Agropecuária Brasileira, Brasília, v. 41, n. 4, p. 697-704, 2006.

VALÉRIO, J. R. Cupins-de-montículo em pastagens. Campo Grande: Embrapa Gado de Corte, 2006. 33 p.

VELOSO, H. P.; RANGEL FILHO, A. L. R.; LIMA, J. C. A. Classificação da vegetação brasileira adaptada a um sistema universal. Rio de Janeiro: IBGE, 1991. 124 p.

VIANA JÚNIOR, A. B.; SOUZA, V. B.; REIS, Y. T.; MARQUES-COSTA, A. P. Termite assemblages in dry tropical forests of Northeastern Brazil: are termites bioindicators of environmental disturbances? Sociobiology, Feira de Santana, v. 61, n. 3, p. 324-331, 2014. 